\title{
Validitas dan Reliabilitas The Brief Illness Perception Questionnaire versi Bahasa Indonesia pada Pasien Diabetes Mellitus
}

\author{
Sofyan Indrayana1, Su Ying Fang2 \\ 1 Program Studi Profesi Ners, Universitas Alma Ata, Yogyakarta, Indonesia \\ 2 Department of Nursing, National Cheng Kung University, Tainan, Taiwan \\ *Correspondence author:Telepon: (0274) 4342288, E-mail:sofindrayana@gmail.com \\ DOI: https://doi.org/10.33859/ dksm.v10i1.397
}

\begin{abstract}
Abstrak
Latar Belakang: Persepsi penyakit adalah konsep dasar dari model akal sehat regulasi kesehatan dan perawatan diri. Persepsi penyakit merupakan salah satu prediktor dari perilaku kesehatan penderita penyakit kronis. The Brief Illness Perception Questionnaire (B-IPQ) adalah salah satu instrumen yang sering digunakan untuk mengukur persepsi penyakit di Indonesia. Namun, informasi tentang validitas dan reliabilitas B-IPQ versi Bahasa Indonesia pada populasi diabetes mellitus (DM) masih belum jelas.

Tujuan: Tujuan dari penelitian ini adalah untuk mengukur validitas dan reliabilitas B-IPQ versi Bahasa Indonesia pada populasi diabetes mellitus.

Metode: Validitas diukur dengan menggunakan indeks validitas isi (CVI) yang dinilai oleh satu dokter spesialis penyakit dalam dan satu perawat. Reliabilitas tes-retest dilakukan pada 10 orang penderita DM dalam waktu dua minggu. Reliabilitas alpha Cronbach dilakukan pada 200 orang penderita DM.

Hasil: CVI dari B-IPQ versi Bahasa Indonesia adalah 1. Sementara itu, hasil reliabilitas test-retest adalah $\mathrm{r}=0,83$ sampai dengan 1 dan reliabilitas alpha Cronbach adalah 0,74.

Simpulan: Versi Bahasa Indonesia dari B-IPQ disimpulkan valid dan memiliki reliabilitas yang baik pada reliabilitas tes-retest maupun reliabilitas alpha Cronbach.
\end{abstract}

Kata kunci: validitas, reliabilitas, B-IPQ, illness perception. 


\title{
Validity and Reliability of the Indonesian version of The Brief Illness Perception Questionnaire in Diabetes Mellitus Patients
}

\begin{abstract}
Background: Illness perception is the central concept of the common-sense model of a health and illness self-regulatory. Illness perception has been found as one of the predictors of health behavior among people with chronic diseases. The Brief Illness Perception Questionnaire $(B-I P Q)$ is one of instruments that used to measure illness perception in Indonesia. However, information about validity and reliability of Bahasa Indonesia version of the B-IPQ for diabetes population is still unclear.

Objective: The purpose of this study was to measure the validity and the reliability of the B-IPQ Bahasa Indonesia version in diabetes mellitus (DM) population.

Methods: The validity was measured by using the content validity index (CVI) which rated by one internist physician and one nurse. Test-retest reliability was performed on 10 people with DM within two weeks. The Cronbach's alpha reliability performed on 200 people with DM.

Result: The CVI of the Bahasa Indonesia version of B-IPQ was 1. Meanwhile, the test-retest was $r$ $=0.83$ to 1 and the Cronbach's alpha reliability was 0.74 .

Conclusion: The Bahasa Indonesia version of B-IPQ was valid and considered have the good reliability either for test-retest reliability or Cronbach's alpha reliability.
\end{abstract}

Key Words: validity, reliability, B-IPQ, illness Perception

\section{Pendahuluan}

\section{Illness perception atau persepsi}

penyakit merupakan konsep inti dari model akal sehat atau common-sense model pada kontrol diri sehat-sakit (Leventhal, Brissette, \& Leventhal, 2003). Menurut konsep ini, kepercayaan dan pandangan pribadi dari seseorang tentang penyakitnya akan mempengaruhi respon terhadap kondisi yang dialaminya (Leventhal, Brissette, \& Leventhal, 2003; Puffelen et al., 2015).
Penyakit atau gejalanya akan menstimulasi representasi dari kognitif maupun emosional atau memunculkan persepsi terhadap penyakit berdasarkan budaya, sosial, kepribadian, pengalaman dan pendidikan yang akan mempengaruhi seseorang untuk mengadopsi rencana prilaku atau strategi koping sebagai rencana solusi permasalahan kesehatan yang dihadapi (Leventhal, Brissette, \& Leventhal, 2003; Puffelen et al., 2015). Kemudian seseorang akan melakukan penilaian terhadap kemungkinan perilaku kesehatan dan 
kemudian seseorang tersebut akan

memutuskan untuk melaksanakan prilaku

kesehatan tersebut atau tidak (Leventhal,

Brissette, \& Leventhal, 2003; Puffelen et al.,

2015; Broadbent et al., 2006; Harvey \&

Lawson, 2009).

Illness perception terdiri dari 9

domain yaitu identity, timeline,

consequences, treatment control, personal

control, understanding, emotional

representation, concerns, dan causal

representations (Basu \& Poole, 2016;

Broadbent et al., 2006; Harvey \& Lawson, 2009; Puffelen et al., 2015). Penjelasan dari 9 domain tersebut adalah sebagai berikut:

- Consequences: menilai aspek kognitif tentang seberapa parah seseorang merasakan penyakitnya akan berdampak pada kehidupan atau merasakan dampak fisik, psikologis, dan finansial dari penyakitnya.

- Timeline: menilai aspek kognitif tentang keyakinan terhadap seberapa lama penyakit tersebut akan terjadi pada kehidupan pasien.
- Personal control: menilai aspek kognitif tentang seberapa besar keyakinan pasien terhadap kemampuan untuk mengontrol penyakitnya.

- Treatment control: keyakinan tentang tritmen atau terapi yang didapat oleh pasien untuk mengontrol penyakit atau keyakinan tentang keefektifan terapi seperti perawatan kaki, olah raga, pemeriksaan kesehatan dan medikasi.

- Identity: keyakinan tentang label penyakit dan gejala yang timbul atau merasa ada gejala akibat penyakitnya.

- Concern: menilai aspek emosional untuk merepresentasikan kesadaran pasien atau seberapa pasien cemas dengan penyakitnya. Merasa sudah memberikan perhatian yang lebih terhadap penyakitnya, artinya pasien sangat memperhatikan penyakitnya sebagai wujud kekhawatiranya.

- Emotional responses: menilai aspek emosional seseorang tentang mood menggambarkan evaluasi seseorang 
terhadap potensi dampak emosional dari penyakitnya. Dengan kata lain, perasaan pasien terhadap kondisinya apakah penyakit tersebut membuat pasien merasa sangat sedih atau tidak.

- Coherence: menilai tentang anggapan pasien bahwa dirinya memahami penyakitnya atau seberapa baik pasien memahami penyakitnya.

- Causal representations: menilai tentang faktor penyebab penyakit yang penting menurut pasien.

\section{The Brief Illness Perception}

Questionnaire (B-IPQ) yang dikembangkan oleh Broadbent (2006) telah digunakan untuk mengukur persepsi penyakit pada pasien dengan penyakit kronis seperti kanker, hipertensi, artritis, dan diabetes mellitus di berbagai negara (Basu \& Poole, 2016; Broadbent, Donkin, \& Stroh, 2011; Broadbent et al., 2006; Norfazilah et al., 2013).

Di Indonesia, B-IPQ telah digunakan untuk mengukur persepsi penyakit di beberapa penyakit kronis seperti kanker dan pasien diabetes mellitus (DM) (Arifin, 2016;
Iskandarsyah et al., 2014). Namun demikian validitas dan reliabilitas dari B-IPQ versi Bahasa Indonesia terutama untuk pasien DM masih belum jelas. Oleh karena itu, penelitian ini bertujuan untuk mengukur validitas dan reliabilitas B-IPQ versi Bahasa Indonesia.

\section{Metode Penellitian}

Kuesioner persepsi penyakit versi singkat atau B-IPQ telah di terjemahkan ke Bahasa Indonesia oleh Kaptein et al (2014) sehingga proses forward-backward translation tidak dilakukan lagi (Kaptein et al, 2014). Dalam penelitian ini validitas dilakukan dengan menggunakan content validity index (CVI) yang di nilai oleh 1 orang dokter spesialis penyakit dalam dan 1 perawat poli penyakit dalam. Kuesioner B-IPQ telah dinilai menggunakan 4 skala penilaian, 1= tidak relevan, $2=$ relevan, $3=$ relevan, $4=$ sangat relevan (Polit, Beck, \& Owen, 2007). Proporsi item-item kuesioner yang diberikan nilai 3 atau 4 oleh kedua penilai (raters) dibagi item total harus tidak krang dari 0.80 (Waltz, 2005). 
Uji reliabilitas kuesioner ini dilakukan dengan test-retest terhadap 18 pasien diabetes mellitus, namun hanya 10 pasien yang bersedia kembali mengisi kuesioner dalam periode 2 minggu. Periode 2 minggu dianggab cukup lama bagi pasien untuk melupakan jawaban awal namun cukup singkat untuk mengalami perubahan pengetahuannya (Deniz \& Alsaffar, 2013). Jawaban pertama responden terhadap B-IPQ kemudian dihubungkan dengan jawaban kedua, yaitu jawaban yang diambil 2 minggu setelah jawaban pertama, menggunakan uji pearson correlation. Reliabilitas kemudian juga di uji dengan alpha cronbach's terhadap 200 responden penderita diabetes mellitus.

\section{Hasil Penelitian}

\section{Content Validity Index}

Uji validitas kuesioner B-IPQ versi Bahasa Indonesia didapatkan hasil content validity index (CVI) adalah 1. Nilai indeks tersebut didapat dari perhitungan dengan rumus sebagai berikut (Waltz, 2005): item B-IPQ yang mendapatkan rating

lebih dari 3 dari kedua raters, dibagi dengan total item (9 item) kuesioner B-IPQ.

\section{Test-retest Reliability}

Uji reliabilitas dengan test-retest reliability dilakukan pada 10 responden. Hasil uji reliabilitas menggunakan test-retest kuesioner B-IPQ versi Bahasa Indonesia didapatkan nilai rentang r 0.83-1 (Tabel 1).

\begin{tabular}{|c|c|c|c|}
\hline No & Item & $r$ & $\boldsymbol{P}$ \\
\hline 1. & $\begin{array}{l}\text { Seberapa besar penyakit diabetes mempengaruhi } \\
\text { hidup anda? }\end{array}$ & 0,83 & 0,004 \\
\hline 2. & $\begin{array}{l}\text { Menurut anda, berapa lama penyakit diabetes } \\
\text { anda akan berkelanjutan? }\end{array}$ & 1,00 & 0,000 \\
\hline 3. & $\begin{array}{l}\text { Menurut anda, seberapa besar anda dapat } \\
\text { mengendalikan penyakit diabetes anda? }\end{array}$ & 1,00 & 0,000 \\
\hline 4. & $\begin{array}{l}\text { Menurut anda, seberapa besar pengobatan } \\
\text { yang anda terima dapat membantu penyakit } \\
\text { diabetes anda? }\end{array}$ & 1,00 & 0,000 \\
\hline 5. & $\begin{array}{l}\text { Seberapa berat gejala yang anda alami sebagai } \\
\text { akibat dari penyakit diabetes anda? }\end{array}$ & 0,83 & 0,004 \\
\hline 6. & $\begin{array}{l}\text { Seberapa besar anda mengkhawatirkan } \\
\text { penyakit diabetes anda? }\end{array}$ & 0,87 & 0,001 \\
\hline 7. & $\begin{array}{l}\text { Menurut anda, seberapa baik anda memahami } \\
\text { penyakit anda? }\end{array}$ & 0,83 & 0,004 \\
\hline 8. & $\begin{array}{l}\text { Menurut anda, seberapa besar penyakit anda } \\
\text { mempengruh anda secara emosional? }\end{array}$ & 0,87 & 0,001 \\
\hline 9. & $\begin{array}{l}\text { Mohon tuliskan secara berurutan tiga faktor } \\
\text { utama yang menurut anda menyebabkan } \\
\text { penyakit diabetes. }\end{array}$ & 1,00 & 0,000 \\
\hline
\end{tabular}

Sedangkan hasil uji reliabilitas kuesioner B-IPQ versi Bahasa Indonesia menggunakan alpha cronbach's pada 200 pasien DM tipe 2 
didapatkan hasil reliability statistics 0,74 .

Interclass correlation kuesioner B-IPQ versi

Bahasa Indonesia didapatkan nilai batas bawah 0,683 dan batas atas 0,792 dengan average measures interclass correlation adalah 0,741 .

\section{Pembahasan}

Content validity index kuesioner BIPQ versi Bahasa Indonesia belum diketahui sebelumnya. CVI kuesioner B-IPQ versi Bahasa Indonesia adalah 1 dengan menggunakan 2 penilai. Hasil CVI tersebut mungkin akan berbeda jika dinilai oleh lebih banyak expert. Namun demikian, nilai CVI 1 pada penelitian ini menunjukkan bahwa kuesioner B-IPQ versi Bahasa Indonesia adalah valid karena tidak krang dari 0.80 (Waltz, 2005).

Uji reliabilitas kuesioner B-IPQ versi Bahasa Indonesia dengan test-retest reliability juga belum diketahui sebelumnya. Namun hasil test-retest reliability B-IPQ versi Bahasa Inggris adalah $(r=0.5$ to 0.7$)$ dan tergolong dapat diterima (Basu \& Poole, 2016; Broadbent et al., 2006). Dalam penelitian ini didapatkan nilai Pearson correlation kuesioner B-IPQ versi Bahasa Indonesia adalah berkisar pada rentang 0,83 sampai 1 . Rentang nilai Pearson correlation pada testretest reliability kuesioner B-IPQ versi Bahasa Indonesia termasuk pada kategori reliabilitas baik (Basu \& Poole, 2016).

Uji reliabilitas menggunakan Cronbach's alpha coefficient kuesioner BIPQ versi Bahasa Indonesia sudah pernah dilakukan pada pasien kanker payudara dengan hasil nilai Cronbach's alpha coefficient adalah 0,70 (Iskandarsyah, Klerk, Suardi, Sadarjoen, \& Passchier, 2014). Pada studi ini, uji reliabilitas B-IPQ versi Bahasa Indonesia yang dilakukakan pada pasien DM tipe 2 didapatkan nilai Cronbach's alpha coefficient 0,74. Nilai Cronbach's alpha coefficient 0,74 tersebut termasuk dalam ketegori reliabilitas baik (Hinton et al., 2004). Validitas menggunakan CVI dari kuesioner B-IPQ versi Bahasa Indonesia tergolong baik. Sedangkan reliabilitas kuesioner B-IPQ versi Bahasa Indonesia menggunakan test-retest dan Cronbach's 
alpha juga tergolong baik. Dari hasil uji

validitas dan reliabilitas yang dilakukan pada

pasien diabetes mellitus tipe 2 menunjukkan

bahwa kuesioner B-IPQ versi Bahasa

Indonesia adalah valid dan reliabel.

\section{Daftar Pustaka}

Arifin, Faisal Fachrul. (2016). Hubungan Antara Persepsi Tentang Penyakit Denga Kepatuhan Minum Obat Hipoglikemik Oral (OHO) di Puskesmas Srondol Kota Semarang (Skripsi). Universitas Diponegoro : Semarang. Retrieved from http://eprints.undip.ac.id/51153/1/PROPO SAL_PENELITIAN_FAISAL_FACHRU R_ARIFIN_22020112110088.pdf.

Basu, S., \& Poole, J. (2016). The brief illness perception questionnaire. Occupational Medicine (Oxford, England), 66(5), 419420.

Broadbent, E., Petrie, K. J., Main, J., \& Weinman, J. (2006). The brief illness perception questionnaire. Journal of psychosomatic research, 60(6), 631-637. doi:10.1016/j.jpsychores.2005.10.020.

Broadbent, E., Donkin, L., \& Stroh, J. C. (2011). Illness and treatment perceptions are associated with adherence to medications, diet, and exercise in diabetic patients. Diabetes care, 34(2), 338-340. doi:10.2337/dc10-1779.

Deniz, M. S., \& Alsaffar, A. A. (2013). Assessing the validity and reliability of a questionnaire on dietary fibre-related knowledge in a Turkish student population. Journal of Health, Population, and Nutrition, 31(4), 497.

Harvey, J., \& Lawson, V. (2009). The importance of health belief models in determining self-care behaviour in diabetes. Diabetic Medicine, 26(1), 5-13. doi:10.1111/j.1464-5491.2008.02628.x.

Hinton, P. R., McMurray, I., \& Brownlow, C. (2004). Spss explained: Routledge.

Iskandarsyah, A., Klerk, C., Suardi, D. R., Sadarjoen, S. S., \& Passchier, J. (2014). Consulting a traditional healer and negative illness perceptions are associated with non-adherence to treatment in indonesian women with breast cancer. Psycho-Oncology, 23(10), 1118-1124. doi:10.1002/pon.3534.

Kaptein, Ad, Erliyani Sartono, Dicky L. Tahapary, dan Magdalena Halim. (2014). B-IPQ Bahasa Indonesia. Retrieved from https://www.uib.no/ipq/pdf/B-IPQIndonesia.pdf.

Leventhal, H., Brissette, I., \& Leventhal, E. A. (2003). The common-sense model of self-regulation of health and illness. The Self-Regulation of Health and Illness Behaviour, 1, 42-65.

Norfazilah, A., Samuel, A., Law, P., Ainaa, A., Nurul, A., Syahnaz, M. H., \& Azmawati, M. N. (2013). Illness perception among hypertensive patients in primary care center UK MMA. Malaysian Family Physician: the Official Journal of the Academy of Family Physicians of Malaysia, 8(3), 19-25.

Polit, D. F., Beck, C. T., \& Owen, S. V. (2007). Is the CVI an acceptable indicator of content validity? Appraisal and recommendations. Research in Nursing \& Health, 30(4), 459-467.

Puffelen, A. L. v., Heijmans, M. J., Rijken, M., Rutten, G. E., Nijpels, G., \& Schellevis, F. G. (2015). Illness perceptions and self-care behaviours in the first years of living with type 2 diabetes; does the presence of complications matter? Psychology \& 
Dinamika Kesehatan Jurnal Kebidanan dan Keperawatan Vol 10 No. 1 Juli 2019 ( ISSN: 2086-3454 EISSN: 2549-4058)

url: http://ojs.dinamikakesehatan.unism.ac.id DOI : https://doi.org/10.33859/ dksm.v10il.397

Validitas dan Reliabilitas The Brief Illness Perception Questionnaire versi Bahasa Indonesia pada Pasien Diabetes Mellitus

health, $\quad 30(11)$, 1274-1287.

doi:10.1080/08870446.2015.1045511.

Waltz, C. F. (2005). Measurement in nursing and health research: Springer Publishing Company 